Van den Brink, Gijsbert

Vrije Universiteit Amsterdam

Protestantse Theologische Universiteit (Amsterdam)

\title{
Vroom en daarom rechtzinnig. Brümmer over het primaat van de geloofsbeleving
}

\begin{abstract}
Pious and therefore orthodox. Brümmer on the primacy of faith experience

In a new (as yet unpublished) manuscript Vincent Brümmer's academic work takes a surprising turn, in that he moves from philosophical theology to historical theology. This paper shows that behind Brümmer's recent historical work (a sample of which has already been published in Brümmer 2010) a strong systematic concern can still be discovered: Brümmer wants to show how the theology of Nicolaas Hofmeyr (1827-1909), Andrew Murray (1828-1917) and their followers was largely determined by their spirituality (which focused on the experience of a personal relationship with God through Christ in the Spirit) rather than the other way around. As mystical theologians, and contrary to the contemporary (Kuyperian and Princetonian) confessionalists, piety was more important to them than orthodoxy - and this is indeed what we should learn from them. In response to this, I suggest that the relation between piety and orthodoxy is more of a synthetical than of an antithetical nature.
\end{abstract}

\section{INLEIDING}

De laatste jaren ontmoeten Vincent Brümmer en ik elkaar minder regelmatig dan in de tijd waarin ik promovendus en later medewerker bij hem was, maar telkens wanneer we elkaar treffen vertelt hij enthousiast over de laatste ontwikkelingen in zijn onderzoek. Van tijd tot tijd stuurt hij ook zijn work in progress daarover toe, en vraagt dan bij onze eerstvolgende ontmoeting belangstellend of ik dat al gelezen heb. De laatste keren moest mijn antwoord op die vraag ontkennend luiden. Brümmers recente onderzoek richt zich op de theologie aan de Universiteit van Stellenbosch in de 19de eeuw, en meer specifiek op de controverse die Andrew Murray en Nicolaas Hofmeyr daar na 1860 voerden met de Kaapse aanhangers van de zogenaamde "Moderne Richting" in Nederland. Het feit dat deze thematiek voor mijn gevoel wat verder van me afstond zal er wel mede debet aan zijn dat ik er gedurende geruime tijd niet toe kwam kennis te nemen van wat Brümmer hierover te melden had.

$\mathrm{Nu}$ er een feestnummer van NGTT samengesteld wordt ter gelegenheid van Vincent Brümmers tachtigste verjaardag eind 2012, biedt dat echter een mooie gelegenheid mijn achterstand in te halen en mij alsnog te verdiepen in de resultaten van Brümmers recente "navorsing". De thematiek daarvan roept immers bij nader inzien toch wel intrigerende vragen op. Brümmer heeft zich gedurende zijn werkzame leven ontwikkeld tot een in Europese kringen vooraanstaand godsdienstfilosoof c.q. wijsgerig theoloog in de analytische traditie. Het netwerk van geleerden dat hij bijeen wist te brengen en waarmee hij seminars, onderzoeksbijeenkomsten en congressen organiseerde omvatte - zo zie ik achteraf scherper dan destijds - zo ongeveer alle topfiguren uit het vakgebied van de analytische godsdienstwijsbegeerte en (wijsgerige) 
theologie in Europa: D.Z. Phillips, Keith Ward, Richard Swinburne, Paul Helm, David Brown, Christoph Schwöbel, Ingolf Dalferth - om er slechts enkelen te noemen. Met al deze productieve en creatieve geleerden bracht hij ons als zijn leerlingen ook in rechtstreeks contact, en dat heeft onze PhD-opleiding en onze academische vorming als geheel zeer in positieve zin gestempeld.

Tegen deze achtergrond wekte het enige bevreemding dat Brümmer zich in zijn onderzoek de laatste jaren op kerkhistorische thema's ging richten. Hoe moesten we dit begrijpen? Is er sprake van een late carrièreswitch, waarbij de discipline van de kerk- en theologiegeschiedenis uiteindelijk meer bevrediging biedt dan de wijsgerige theologie? Of hebben wij van doen met een hoogleraar die zich na zijn emeritaat niet langer hoeft te bewijzen op zijn vakgebied, en daarom bij wijze van hobby gaat liefhebberen in de lokale kerkgeschiedenis van zijn geboortegrond? Mijn intuïtie is dat geen van beide het geval is. Ik vermoed dat Brümmer ook in de huidige fase van zijn leven nog altijd wel degelijk met zijn vakgebied bezig is, maar dat nu over de band van de kerkgeschiedenis doet. Dat is dan ook de werkhypothese die ik in deze bijdrage wil toetsen. Het zal daarbij blijken dat het inderdaad geen pure historische nieuwsgierigheid is die Brümmer drijft, maar een theologische grondovertuiging. Aan de hand van de kerk- en theologiehistorische ontwikkelingen te Stellenbosch in de $19^{e}$ eeuw wil Brümmer een systematisch punt maken. Het betreft een punt dat in zijn eerdere oeuvre ook al oplicht, maar dat kennelijk steeds centraler is komen te staan in zijn denken, en dat hij daarom nog eens afzonderlijk in een ander ( $\mathrm{nl}$. historisch) gewaad aan de orde wil stellen.

In dit opstel wil ik allereerst de lijn van Brümmers theologiehistorische betoog volgen en aangeven welke stappen hij daarin zoal zet, zodat we zijn gedachtegang zo zorgvuldig mogelijk in beeld krijgen. Conform zijn eigen invalshoek zullen we daarbij speciaal letten op hoe Brümmer in zijn theologiehistorisch vertoog de verhouding tussen geloofsbeleving en geloofsleer schetst (par.2). Daarna ga ik speciaal hierover met Brümmer in gesprek en stel enkele vragen bij de wijze waarop hij deze relatie stelt. Nu Brümmer zich zo diepgaand op zijn eigen kerkelijke traditie bezint, veroorloof ik me daarbij ook een klein uitstapje naar de mijne (die van de zogeheten "Gereformeerde Bond"). Ik zie opmerkelijke overeenkomsten, maar denk tegelijkertijd dat de relatie tussen geloofsbeleving en geloofsleer zowel historisch als systematisch anders gesteld moet worden dan Brümmer suggereert (par.3). Ik sluit af met een korte wens bij wijze van conclusie (par.4). ${ }^{1}$

\section{MODERNITEIT, CONFESSIONALISME EN GELOOFSERVARING IN DE NG KERK}

In zijn te verschijnen boek bespreekt Brümmer enkele spraakmakende theologische controverses in de N.G. Kerk gedurende de jaren 1860-1870. Allereerst onderzoekt hij de reacties van twee beeldbepalende N.G. theologen van destijds, Nicolaas Hofmeyr en Andrew Murray, op de moderne richting zoals die vanuit Nederlandse invloeden in de Kaap was opgekomen. Aan de hand van enkele van hun publicaties beschrijft Brümmer daartoe de theologie en spiritualiteit van Hofmeyr en Murray. Hij werkt daarbij met uitvoerige citaten, zodat de lezer de geloofsbeleving van beiden als het ware kan proeven. Het blijkt dat beiden weliswaar verschillende accenten leggen, maar dáárin een zijn dat de beleving van het geloof als persoonlijke relatie met God belangrijker is dan de leer van de kerk. Beiden blijken tijdens de studiejaren die zij in Utrecht

1 Het geheel van dit artikel staat onder een voorbehoud, aangezien ik inga op een nog niet gepubliceerde tekst van Brümmer: 'Vroom of regsinnig? Teologie in die N.G. Kerk', 132 pp.; ontvangen van de auteur op 31 oktober 2012 met de mededeling dat hij 'nog bezig [is] met een laatste hoofdstuk dat ik af wil maken' (persoonlijke correspondentie). Dit typoscript kan dus nog in meer of mindere mate aangepast worden. Maar ook als dat het geval zou zijn, markeert het een interessante fase in Brümmers interactie met de theologie en spiritualiteit die zijn opvoeding gestempeld hebben. Overigens is een deel van het typoscript reeds verschenen als voorpublicatie: Brümmer 2010. 
doorbrachten te zijn aangeraakt door de $19^{\mathrm{e}}$ eeuwse Europese opwekkingsbeweging die onder meer in Nederland de gestalte aannam van het zogeheten Réveil. Daarbij lijken met name bij Murray (die behalve in Utrecht ook in Schotland gestudeerd had) daarachter ook methodistische invloeden een belangrijke inspiratiebron te zijn geweest. De liefde van God in Christus was voor Murray de centrale hoofdwaarheid van het christelijk geloof, en hij verbond deze (goed methodistisch?) met een streven naar persoonlijke levensheiliging. Hofmeyr formuleerde het "kindschap van God" als de kern van waar het in het geloof om draait, en contrasteerde dat sterk met een "knechtelijk" (lees: zakelijk-contractueel) gedachte verhouding tussen God en mens.

Vervolgens gaat Brümmer in op de opkomst en theologische eigenheid van de Kaapse "moderne richting". Leidinggevende theologen binnen deze beweging waren J.J. Kotze, T.F. Burgers en D.P. Faure. Alle drie hadden zij in Nederland gestudeerd, en waren zij via de Utrechtse filosoof C.W. Opzoomer onder invloed gekomen van toonaangevende "moderne" theologen te Leiden, zoals A. Kuenen, L.W.E. Rauwenhoff en vooral J.H. Scholten. Eenmaal terug in Zuid-Afrika zetten zij zich in voor de verspreiding van het moderne gedachtengoed. Zij werden daarbij geholpen door de landmeter Leopold Marquard (een zwager van Faure), die redacteur was van het tijdschrift De Onderzoeker dat vanaf 1860 de moderne richting in de Kaap propageerde. Kotze en Burgers behoorden tot de N.G. Kerk, maar Faure studeerde enkele jaren later af en mocht vanwege een synodebesluit uit 1862 niet meer op basis van zijn Nederlands proponentsexamen N.G. predikant worden. Hij zou daartoe een in confessioneel opzicht "streng" Zuid-Afrikaans colloquium af moeten leggen, en besloot om in plaats daarvan te Kaapstad een Vrye Protestantse Kerk te stichten. Deze zou in de loop der jaren onderdak gaan bieden aan vele vrijzinnige inwoners van de Kaap, onder wie ook Marquard. Vooral met deze vier voormannen van de moderne richting zouden Hofmeyr en Murray het debat aangaan.

Waar ging het om in dit debat? Normaal gesproken zou men verwachten: over de ware leer die in de kerk verkondigd dient te worden. Hofmeyr en Murray zouden dan gemakkelijk gezien kunnen worden als vertegenwoordigers van het orthodoxe establishment. Op dit punt doet Brümmer echter een belangrijke observatie. Wat Hofmeyr en Murray dreef was zijns inziens niet zozeer zorg om de belijdenis van de kerk of om de zuiverheid van de christelijke leer, maar om "rechtzinnigheid in het hart". ${ }^{2}$ Met andere woorden: het ging hen om het geleefde geloof, om de "heilige en tere verhouding tussen God en mens" (Hofmeyr 1868: 11; geciteerd bij Brümmer 2012: 33). Bij Hofmeyr is dit overigens duidelijker dan bij Murray. Die laatste moest soms "schipperen" omdat hij als moderator van de N.G. synode ook geacht werd op te komen voor de officiële kerkelijke leer. Hofmeyr lijkt dan ook Brümmers eigenlijke held. Hij noemt hem één van de meest oorspronkelijke en scherpzinnige theologen die de N.G. Kerk ooit heeft voorgebracht (Brümmer 2010: 27). Anders dan Andrew Murray is Hofmeyr echter vandaag zo goed als vergeten. Vandaar Brümmers inspanningen om vooral Hofmeyr en zijn theologische betekenis opnieuw voor het voetlicht te brengen.

Hofmeyr blijft ook belangrijk in het vervolg van Brümmers onderzoek, waarin deze vanuit de zestiger jaren van de negentiende eeuw lijnen doortrekt tot ver in de twintigste eeuw. In het eerste kwart van de twintigste eeuw vindt in de N.G. Kerk als geheel en ook aan de Kweekschool te Stellenbosch een opmerkelijke verschuiving plaats in confessionalistische richting. Theologen die hun studies na de Boerenoorlog niet langer te Edinburgh of Utrecht voort wilden zetten, hadden in plaats daarvan gekozen voor de VU Amsterdam en voor Princeton. ${ }^{3}$

2 Het is opvallend dat Brümmer deze uitdrukking (samen met de contrastterm 'regsinnigheid van die leer') door het hele manuscript heen regelmatig aan Hofmeyr toeschrijft, maar nergens de context ervan geeft of een vindplaats noemt.

3 Zie hierover Schutte 2010. Schutte laat in dit artikel overigens ook zien, dat men ervoor op moet passen een rechte lijn te trekken tussen de Kuyperiaans-confessionalistische invloeden in de Zuid-Afrikaanse 
Velen van hen waren daardoor met orthodoxe ideeën van respectievelijk Kuyperiaanse of fundamentalistische snit thuis gekomen en N.G. predikant geworden. Brümmer laat zien hoe dat op den duur tot botsingen leidde, niet alleen met het modernisme maar ook met het piëtistisch klimaat dat tot dusver in de N.G. Kerk vigeerde. Brümmers onderzoek biedt al met al een prachtige dwarsdoorsnede van de kerk- en theologiegeschiedenis - maar vooral ook van de spiritualiteitsgeschiedenis - van de gereformeerden aan de Kaap. We zien hoe vrijwel alle stromingen en richtingen uit het Nederlandse gereformeerd protestantisme er hun pendant hadden, en hoe dat leidde tot soortgelijke conflicten als in Nederland tussen orthodoxen en modernen over de inspiratie van de Bijbel, de historische Bijbelkritiek, de waardering van de contemporaine wetenschap, predestinatie en vrije wil, de godheid van Christus, de aard van de verzoening tussen God en mens, et cetera.

We zien echter ook hoe zich te midden van die botsingen een "etiese rigting" uitkristalliseert, die enerzijds openstaat voor nieuwere ontwikkelingen in wetenschap en cultuur maar anderzijds probeert deze te interpreteren op een manier die te rijmen valt met de geest van het Réveil. Hier meldt zich dus weer de stroming van Murray en (vooral) Hofmeyr, met wie het allemaal ooit begonnen was aan de Kweekschool te Stellenbosch. Juist deze stroming blijkt als het ware de rode draad te vormen door de studie van Brümmer heen. Vertegenwoordigers van deze ethischirenische stroming organiseren in 1910 een symposium in Montagu, en haast terloops meldt Brümmer ons dat één van de referaten daar gegeven werd door ene ds. N.J. Brümmer (Brümmer 2012: 97). Deze was destijds predikant te Drieankerbaai, maar zou van 1911 tot 1941 werkzaam zijn als hoogleraar filosofie te Stellenbosch (Brümmer 2012: 99). Ook al is Vincent Brümmer te bescheiden om dit te vermelden (of wil hij gewoon objectief blijven), het gaat hier om zijn vader en we krijgen langs deze weg dus meteen een inkijkje in de geestelijke atmosfeer waarin hijzelf is opgegroeid. J. Muis merkt elders in dit nummer dan ook terecht op dat Brümmer "in de traditie staat van de zogenoemde 'ethische theologie', waarin niet de kerkelijke belijdenis maar de liefdesgemeenschap met Christus de toon aangeeft". ${ }^{4}$

Brümmer (2012: 100-101) tekent de spirituele en theologische sfeer van Montagu aan de hand van vier kenmerken. (1) Het geloof is niet zozeer intellectueel als wel existentieel ("ethisch") van aard; dat wil zeggen: het gaat niet om cognitieve aanvaarding van confessionele standpunten, maar om de vormgeving van het leven vanuit de persoonlijke liefdesverhouding met God, en de interpretatie van het leven in de wereld in het licht hiervan. Geloofskennis is dus iets anders dan praktische kennis. (2) In het verlengde hiervan moet in de Bijbel onderscheiden woorden tussen feiten en waarheid. De feiten zijn natuurlijk wel belangrijk, maar alleen in zoverre ze de noodzakelijke vooronderstellingen vormen van de existentiële geloofswaarheid; daar waar dat niet het geval is, staan ze volstrekt open voor wetenschappelijke toetsing en kritiek. De Bijbel is immers niet bedoeld om ons allerlei informatie te geven, maar om ons "wijs te maken tot zaligheid" (2 Tim.3:15). (3) Alleen daar waar de wetenschap hypotheses ontwikkelt die aantoonbaar de existentiële waarheid van het geloof ondergraven, trekt het geloof een duidelijke grens. Vandaar dat de ethischen destijds de modernen bestreden, die deze grens naar hun inzicht immers overschreden. (4) Gelovigen moeten onbevooroordeeld staan tegenover de bevindingen van wetenschappelijk onderzoek, en het behoort tot de taak van de theologie om deze bevindingen (voorzover ze goed gefundeerd zijn) met het geloof in verband te

theologie en de latere apartheidsideologie - een gangbare simplificatie waar ook Brümmer niet helemaal aan lijkt te ontkomen (vgl. Brümmer 2012:3, noot 4). Kuypers spiritualiteit verschilde (anders dan zijn theologie) misschien ook wel niet zozeer van die van Hofmeyr en Murray als men misschien zou denken - men leze bijv. eens Kuyper 1901, waar hij voorafgaand aan "mysticisme" en "practicisme" het "intellectualisme" bespreekt als de eerste "zonde, waarvoor het Gereformeerde kerkelijk leven bloot ligt" (1)

4 Muis 2012, p.2 van het typoscript; Muis baseert deze waarneming op Brümmer 2010. 
brengen. Op dit punt verschilden de ethischen van de meer confessioneel ingestelde orthodoxgereformeerden in de NG Kerk, die dit streven met achterdocht bejegenden.

Dicht in de buurt van de ethischen tekent Brümmer in een apart hoofdstuk nog de "BybelsApologetiese Skool", die sterk verwant was aan de gelijknamige Utrechtse stroming waarvan J.I. Doedes en J.J. van Oosterzee de voornaamste vertegenwoordigers waren. In Stellenbosch kreeg deze stroming gedurende het eerste kwart van de twintigste eeuw gestalte in het werk van de Kweekschool-hoogleraren J.I. Marais (1848-1919), A. Moorrees (1855-1938), P.J.G. de Vos (18421931) en C.F.J. Muller (1845-1915). Hun theologie was behoudender dan die van de ethischen, maar hun spiritualiteit irenisch.

Opvallend is dat naarmate we het tweede kwart van de twintigste eeuw ingaan zowel de ethische als de apologetische school door Brümmer steeds dichter in de buurt van de modernen gepositioneerd worden. Alle drie deze groeperingen lijken zich te verenigen in de strijd tegen wat zij zagen als een (via de invloed van Hodge en vooral Kuyper) opgekomen confessionalistisch front in de NG Kerk. Hadden ze door de opkomst van deze nieuwe stroming onderling steeds minder appels met elkaar te schillen? In elk geval blijkt van de onderlinge verschillen van inzicht weinig meer wanneer Brümmer een tweede controverse in de NG-Kerk bespreekt. Deze cirkelt rond de figuur en theologie van Johannes du Plessis (1868-1935); zoals Hofmeyr de hoofdpersoon is in het eerste deel van Brümmers studie, is Du Plessis dat in het tweede. Du Plessis was in 1916 benoemd tot hoogleraar te Stellenbosch als opvolger van de bovengenoemde Muller. Hij was opgegroeid in de sfeer van de ethische theologie en als zodanig een leerling van Hofmeyr, trad als spreker op tijdens het symposium in Montagu (1910), maar ontwikkelde zich naderhand de facto steeds nadrukkelijker in moderne richting. Hij pleitte bijvoorbeeld voor een prediking waarin ingegaan werd op de nieuwe bevindingen van de wetenschap, zodat voor studenten en intellectuelen duidelijk zou worden dat deze niet in strijd waren met het christelijk geloof. Dat kwam hem in 1912 op kritiek te staan van niemand minder dan Andrew Murray, die van mening was dat een dergelijke prediking alleen maar twijfel zou zaaien en het geloof in Gods Woord zou ondermijnen (Brümmer 2012: 102).

Helaas was Hofmeyr in het jaar voorafgaand aan het symposium in Montagu overleden, zodat we nooit zullen weten hoe hij op de stellingname van Du Plessis zou hebben gereageerd. Dat geeft Brümmer de ruimte om te betogen dat Du Plessis in zijn pleidooi voor openheid jegens nieuwe ontwikkelingen een "navolger van Hofmeyr" was. Het merkwaardige daarvan is dat Brümmer zelf in een eerder hoofdstuk juist met enige uitvoerigheid beschreven heeft hoe buitengewoon kritisch Hofmeyr reageerde op de moderne richting. Weliswaar maakt Brümmer duidelijk dat Hofmeyrs kritiek een speciaal karakter had: ze was veelmeer spiritueel en existentieel van aard dan leerstellig. Dat wil echter niet zeggen dat ze minder fel of minder duidelijk was, integendeel. Het moderne wereldbeeld ondergroef zijns inziens immers de "zo heilige en tere" liefdesrelatie tussen God en mens (Brümmer 2012: 33). Zij raakte het christelijke geloof volgens Hofmeyr dus in het hart. Het kan liggen aan de wijze waarop Brümmer zijn materiaal selecteert, maar als het gaat over Du Plessis horen we niets van dit alles. Zijn openheid jegens cultuur en wetenschap én zijn afkeer jegens elke vorm van confessionalisme lijken hem op den duur elke kritische zin jegens de moderniteit te hebben doen verliezen. Behalve tegen het confessionalisme richt Du Plessis zijn pijlen vooral nog tegen de (rechtzinniger, maar zeker niet on-mystieke) Doppers uit Potchefstroom en tegen de Rooms-Katholieke Kerk (Brümmer 2012: 121). Wanneer Brümmer dus schrijft dat Du Plessis in zijn kerkelijke opstelling een trouw volgeling van Hofmeyr was, valt daar dus misschien wel het een en ander op af te dingen. Op z'n minst moet Brümmer toegeven dat Du Plessis een nogal polemische instelling had (Brümmer 2012: 120), wat naar het mij voorkomt inhoudt dat hij minstens in dat opzicht afweek van de (ethisch-)irenische geest van het Reveil. 
Hoe dit ook zij, de ontwikkelingen komen tot een dramatisch hoogtepunt (of dieptepunt) wanneer in februari 1930 Du Plessis door een buitengewone synode van de NG Kerk vanwege gebleken onrechtzinnigheid voor onbepaalde tijd wordt geschorst als hoogleraar. Dat het Kaapse Hooggerechtshof die beslissing later onjuist acht en een volgende synode, van 1932, zich daarbij neerlegt, mag niet meer baten. Du Plessis mag weliswaar zijn salaris en pensioenrechten behouden, maar keert gezien de onwerkbaar geworden verhoudingen niet terug als hoogleraar aan de Kweekschool. In zijn plaats en die van een emeriterende collega worden twee "Princetonfundamentalisten" (Brümmer 2012: 126) benoemd, en samen met de Kuyperianen zullen de Princetonianen de daarop volgende decennia de dienst uitmaken in de NG-Kerk. Het betekent een einde aan elk debat over theologische vernieuwing en een toenemend isolement op oecumenisch gebied. Brümmer tekent het als een ontwikkeling die wezensvreemd is aan de oorspronkelijke geest van de NG Kerk, en afbreuk doet aan haar ethisch-irenische karakter in de sfeer van het Reveil (bijv. op p.121 vanuit Du Plessis en op p.126 vanuit Deist 1986). Op die manier geeft hij een duidelijk eigen accent mee aan zijn relaas over de geschiedenis van de NG Kerk. Dat brengt me bij enkele vragen die de lectuur van zijn nieuwe boek oproept.

\section{ENKELE VRAGEN}

Ook al probeert Brümmer zich namelijk vooral op te stellen als "onpartijdig" historicus, toch blijft zoals we zagen niet onduidelijk waar zijn sympathieën liggen. Methodisch is het interessant dat hij in zijn samenvattende weergaves van de opvattingen van hem sympathieke theologen haast ongemerkt het stokje van hen kan overnemen. Soms is daardoor niet helemaal duidelijk of hij Hofmeyr, Murray of later Marais parafraseert dan wel voor eigen rekening spreekt. Gaat het echter om vertegenwoordigers van eerst de moderne en later de orthodox-confessionele richting, dan plaatst hij regelmatig kritische evaluerende kanttekeningen. Zijn als historisch gepresenteerde betoog gaat op deze manier gepaard met theologische oordelen - Brümmers achtergrond als systematicus verloochent zich niet.

Trouwens, alleen al in de manier waarop hij het historische verhaal vertelt bevindt zich een bepaalde tendens. Het is immers duidelijk dat Brümmer de geschetste ontwikkeling van een ethisch-irenische naar een meer confessioneel geijkte spiritualiteit in de NG Kerk zeer betreurt, en er een wezensvreemde afwijking in ziet van haar oorspronkelijke Anliegen. De vraag is echter of dit oorsponkelijke Anliegen voor altijd bepalend zou moeten zijn voor de NG Kerk. Juist Brümmer leerde ons in dit verband om kritisch te zijn jegens elk 'essentialisme' in de kerk en theologie (vgl. Brümmer 2006: 375-390). Het is dan ook wat merkwaardig dat hij in dit geval kennelijk juist wil vasthouden aan een gelijkblijvende kern, en wat romantisch blijft terugverlangen naar "hoe het altijd geweest is"? Net als cultuur en wetenschap zijn ook kerken in ontwikkeling. En soms bewegen zij zich door de omstandigheden ineens in een meer orthodoxe en confessionele richting. Beter dan zulke ontwikkelingen te veroordelen is het - zeker voor wie zich er in historische zin toe wil verhouden - om na te gaan hoe ze in hun samenhang begrepen kunnen worden, en wellicht gewaardeerd als adequate reactie op nieuwe omstandigheden die zich in de tijd voordoen. ${ }^{5} \mathrm{Nu}$ was het echter ook niet Brümmers bedoeling

5 Men kan zich bijvoorbeeld afvragen of een grote openheid voor nieuwere ontwikkelingen in cultuur en wetenschap uiteindelijk niet secularisatie-bevorderend werkt. In Nederland lijkt het er in elk geval sterk op dat kerken en groeperingen die zich hier juist kritischer en met meer distantie toe verhouden beter in staat zijn het geloof op een volgende generatie over te dragen. Wanneer dit in Zuid-Afrika ook zo zou zijn (en het zou me verbazen als dat niet zo was), zou het dus wel eens van wijsheid kunnen getuigen dat de NG Kerk in haar strijd tegen het modernisme (Murray en Hofmeyr!) op den duur behoefte kreeg aan een wat belijnder confessioneel en leerstellig kader. Vanuit onder meer Kuyper kon vervolgens aan die behoefte tegemoet gekomen worden. 
om een neutrale weergave van de ontwikkelingen in de NG Kerk te bieden. Brümmer weet veel te goed dat dat niet mogelijk is - hij bracht ons destijds óók het nodige bij over de betekenis van recente hermeneutische theorievorming zoals die van H.G. Gadamer (vgl. Brümmer 2006: 433-452). Brümmer opent zijn studie dan ook met expliciet te maken vanuit welk perspectief hij naar het verleden wil kijken. Dat is het perspectief van een onderscheid dat zijns inziens door heel de geschiedenis van de NG Kerk heen zichtbaar is, namelijk tussen wat hij noemt confessionalisten en mystici. Dit onderscheid is echter niet altijd openlijk uitgesproken en was ook niet steeds scherp, doordat veel gelovigen en theologen intuïtief geprobeerd hebben om mystiek en confessie in hun geloofsbeleving te verenigen. Brümmer acht het onderscheid echter wel van groot belang, en zijn studie is er dan ook op gericht het weer naar voren te halen. De doelstelling van zijn boek formuleert hij in dit verband als volgt: "In wat volg wil ek probeer om hierdie twee tendense [ $\mathrm{nl}$. confessionalisme en mystiek, GvdB] te ondersoek aan die hand van die twee groot teologiese kontroverses in die N.G. Kerk gedurende die afgelope 150 jaar: Die stryd teen die sogenaamde 'Moderne Rigting' in die 1860's en die stryd rondom professor Johannes du Plessis in die 1920's" (Brümmer 2012, 2-3). Vanuit dit specifieke perspectief kijkt Brümmer dus naar de geschiedenis, en het is goed dat hij hierover van meet af aan duidelijkheid verschaft.

Maar hoe verhelderend is het perspectief precies? Hoe raak zijn om te beginnen de trefwoorden? Een woord als "confessionalisme" kan haast alleen maar pejoratief gebruikt worden. Door het in een historische studie als sleutelterm te hanteren, verliest de historicus eigenlijk meteen zijn onpartijdigheid. Want een confessionalist wil natuurlijk niemand zijn - ik ken althans geen mensen die deze term als adequate weergave van hun (kerkelijk) zelfverstaan beschouwen. Brümmer definieert de term ook niet heel nauwkeurig, maar het gaat hem duidelijk om gelovigen bij wie de belijdenis van de kerk bepalend is voor hun geloofsbeleving. Wellicht zou men in dit verband, neutraler, over confessionelen kunnen spreken, of over op de kerkelijke belijdenis georiënteerden. Bij Brümmers mystici ligt de verhouding tussen leer en beleving precies omgekeerd: bij hen is de geloofsbeleving, meer concreet: de beleving van de persoonlijke relatie met God in Christus, bepalend voor de leer. Op deze manier is het contrast dus scherp te krijgen.

Meer nog dan bij "confessionalisme" vraag ik me echter of "mystiek" wel een goede aanduiding is van wat Brümmer voor ogen staat. Opvallend is dat hij, evenals in andere publicaties waarin hij deze term op de voorgrond stelt, haar onmiddellijk moet kwalificeren (bijv. in Brümmer 2010, 26-27; vgl. ook Brümmer 2006, 317-331). Het gaat hem niet om een spiritualiteit die slechts aandacht heeft voor het innerlijke zelf en niet voor de wereld. Evenmin gaat het om een - al dan niet oosterse - "eenheidsmystiek" die streeft naar extatische eenwording met het goddelijke. Brümmer denkt veeleer aan een vroomheid die gestempeld wordt door de persoonlijke gemeenschap met Christus en de persoonlijke ervaring van Zijn liefde. Om het met woorden van Andrew Murray te zeggen: de persoonlijke omgang met Christus en de persoonlijke ondervinding van Zijn grote liefde zijn de hoofdzaak van het christendom (Murray 1905: vii-viii; vgl. Brümmer 2010: 25; 2012:7). Van een opgaan in God of het goddelijke waarbij de grens tussen Schepper en schepsel wordt uitgewist is dus geen sprake. Maar dat is nog wel altijd de eerste associatie die velen bij de term mystiek hebben. Al is er op zichzelf niets mis met de term als zodanig (ook niet in de gereformeerde traditie: iemand als Calvijn sprak ook al over een unio mystica cum Christo), de vraag is daarom of niet beter voor een andere, minder ambivalente aanduiding gekozen kan worden.

Zelf ben ik groot geworden en beweeg ik me nog altijd in de Gereformeerde Bond - ook ooit ontstaan uit een kerkelijk-theologische controverse over modernisme (vgl. Graafland 1981), maar opvallend genoeg één van de weinige stromingen uit het Nederlands protestantisme die in 
Zuid-Afrika geen pendant lijkt te hebben gekregen. Ook binnen de Gereformeerde Bond is altijd groot belang gehecht aan de concrete beleving van het geloof en de praktische omgang met Christus. Zonder een dergelijke persoonlijke omgangskennis zit het geloof "een voet te hoog", zo heette het - namelijk in het hoofd in plaats van in het hart. Voor dit existentiële karakter van de geloofskennis ijkte men in deze traditie echter de term bevinding (vgl. bijv. Quispel e.a. 1976). Men ontleende dit begrip aan de Statenvertalingtekst van Rom.5:4 - "[... wetende, dat] de lijdzaamheid bevinding [werkt], en de bevinding hoop" - en vatte bevinding daarbij op als het proefondervindelijk aan de weet komen van wie God is. "Bevinding" is feitelijk hetzelfde als "ondervinding", dus ervaring. De Engelse vertaling van "bevindelijk" die ik tegenkwam in Nederlandse immigrantenkringen te Grand Rapids (MI) luidt: experiential. Het gaat inderdaad om de ervaring die de gelovige in het leven met God opdoet, waarbij enerzijds verdriet over de eigen zondigheid een plaats heeft en anderzijds blijdschap over het overweldigende van Gods liefde alsook dankbaarheid die zich uit in concrete goede werken. Dat zijn categorieën die ik onmiddellijk terug herken in Brümmers beschrijving van de spiritualiteit van Murray en Hofmeyr. In die zin zou men hun theologie (en als Brümmers continuïteitsthese klopt ook die van Du Plessis) ook, en minder ambivalent, kunnen typeren als bevindelijk. Wie dat te wereldvreemd in de oren klinkt ${ }^{6}$ zou ook nog voor een term als piëtistisch kunnen opteren.

Belangrijker dan de terminologie is echter hoe Brümmer zijn sleutelbegrippen inhoudelijk met elkaar in verband ziet staan. Op dit punt komen enkele verdergaande vragen op. Het is duidelijk dat Brümmer in sterk contrasterende zin over confessionalisme en mystiek wil spreken. Dat blijkt meteen al uit de opvallende disjunctie in de titel: vroom óf rechtzinnig? De mysticus is kennelijk het één, de confessionalist het ander. Of met woorden die Brümmer ontleent aan G.K. Chesterton: voor de mysticus is het geloof "a thing like a love affair", voor de confessionalist "a thing like a theory" (Brümmer 2012: 2). Al spoedig blijkt echter dat het zo eenvoudig toch niet kan zijn. Bij de mystici mag de leer dan niet voorop staan, zij stellen toch wel grenzen aan de relativering ervan. In de hoofdstukken waarin Brümmer de kritiek van Hofmeyr en Murray op de moderne richting bespreekt blijkt waar zij die grenzen stellen: niet daar waar aanhangers van de moderne richting afwijken van de kerkleer of de belijdenisgeschriften, of andere ideeën hebben over de historiciteit van de Bijbel (dat zijn volgens Hofmeyr "ondergeschikte punten"), maar daar waar zij met hun gedachten de spiritualiteit van de gelovige omgang met God ondergraven. Dat doen de modernen (in de lijn van Nederlandse inspiratoren als J.H. Scholten) met name door hun pantheïsme en hun determinisme, welke twee een persoonlijke relatie met God immers onmogelijk maken.

Nu doet Brümmer het voorkomen alsof het met de kritiek van Hofmeyr c.s. op de modernen nog wel wat meeviel. Men krijgt de indruk dat de kritiek die de "confessionalisten" later zouden uitoefenen op elke moderniseringsbehoefte in de kerkelijke theologie veel forser was. Toch is dat nog maar de vraag. In zijn Leerredenen roept Hofmeyr ergens uit: was het maar waar dat het geschil met de modernen uitsluitend betrekking had op een kerkelijk leerstelsel - het is veel erger (Hofmeyr 1868: 17)! Niet voor niets was Hofmeyr destijds de eerste die de Kaapse modernen aanviel. Het ging daarbij wat hem betrof niet maar om het al of niet open staan voor de historische bijbelkritiek. Nee, "die een vraag wat vóór alle ander vrae beantwoord moet word, is dit: 'Is dit waar of nie waar nie, dat die sondaar deur God se heilige toorn en deur die onheilige mag van die sonde van God geskei is, en alleen deur die bloed en die gees van Christus in die gemeenskap van God herstel kan word? Met hierdie vraag staan of val die ganse

6 Betreurenswaardig is intussen, dat de term sinds Janse 1985 verschoven is van een theologische naar een sociologische categorie; ze denoteert vooral nog een bepaalde bevolkingsgroep die zich aan de hand van uiterlijke kenmerken (kleding etc.) laat karakteriseren (de zogeheten 'refo's'), en heeft daardoor in Nederland een beperktere actieradius gekregen. 
Bybel en die ganse Christendom' (Hofmeyr 1868: 59; Brümmer 2012: 32). Bij zo 'n citaat denk ik: een Gereformeerde Bonder zou het exact zo kunnen zeggen. Inderdaad: de gemeenschap - de bevindelijke omgang - met God staat hier voorop. Maar onmiddellijk is duidelijk dat deze kennelijk niet los verkrijgbaar is. Zij hangt blijkens dit citaat voor Hofmeyr in elk geval onlosmakelijk samen met een verzoeningsleer, die hier (anders dan Brümmer suggereert, 12) toch wel anselmiaans van karakter lijkt. Want "alleen door het bloed ... van Christus" is het mogelijk om weer in de gemeenschap van God opgenomen te worden - een visie waarvan Marcel Sarot elders in dit tijdschrift laat zien dat Brümmer deze wel graag wil onderschrijven, maar daar gezien andere delen van zijn theologie eigenlijk maar nauwelijks toe in staat is (Sarot 2012: 9 [typoscript]).

Maar ook als Brümmer deze woorden van Hofmeyr wel volmondig zou bijvallen (of misschien dankzij Hofmeyr van mening veranderd is?), blijft staan dat het hier om een leerstellig gegeven gaat dat als zodanig ook in de confessie van de kerk is opgenomen (bijv. in de Heidelbergse Catechismus, zondag 4-6). lets soortgelijks geldt voor Hofmeyrs spreken over de Geest van Christus door wie de mens geheiligd wordt. Ook dat is een typisch gereformeerd theologoumenon en als zodanig behalve een geloofservaring een leerstellig gegeven. Trouwens, ook uit de meer thetische bespreking van Hofmeyrs spiritualiteit die Brümmer geeft, blijkt dat deze spiritualiteit nauw verbonden was met allerlei dogmatische visies, bijvoorbeeld op de verzoeningsleer, de kerkleer, de leer van de wedergeboorte, de pneumatologie, de voorzienigheids- en verkiezingsleer, eschatologie et cetera (vgl. Brümmer 2010: 27-33, en over de eschatologie 39: "julle gaan met die dwaling verlore"). Brümmer laat fraai en overtuigend zien hoe al deze "leerstukken" door Hofmeyr hernomen worden vanuit het centrale belang van de persoonlijke relatie van de gelovige met God in Christus. De propositionele aanspraken van de geloofsleer vallen in die zin niet samen met het geloof maar zijn, zoals Brümmer ook vaak zegt als hij voor eigen rekening spreekt, te beschouwen als de noodzakelijke vooronderstellingen ervan. Als dat echter zo is, zijn ze toch niet minder (maar eerder meer) van belang? Men kan dan vroomheid en rechtzinnigheid toch niet eenvoudig tegen elkaar uitspelen? Veeleer moet men dan zeggen: geen vroomheid zonder rechtzinnigheid, en geen persoonlijke geloofsrelatie zonder confessie. Hofmeyrs felle polemiek tegen de Moderne Richting moet naar het mij voorkomt overduidelijk vanuit dit besef verklaard worden. Brümmer daarentegen lijkt meer te suggereren, dat als men maar vroom is het er niet meer zo toe doet of men al of niet rechtzinnig is. Dat zou Hofmeyr als ik hem goed begrijp nooit zo zeggen. Vroomheid en rechtzinnigheid lijken bij hem juist nauw met elkaar verstrengeld, net zoals dat trouwens het geval was in de "voorwerpelijk-onderwerpelijke" prediking waarmee ikzelf ben opgegroeid in de Gereformeerde Bond. Het enige waar Hofmeyr terecht niet mee uit de voeten kon was een rechtzinnigheid die geheel van de doorleefde geloofsrelatie was losgemaakt, en daardoor verstard en versteend was geraakt - het soort "dode rechtzinnigheid" dat hij in het Nieuwe Testament terugvond bij Farizeeën en Schriftgeleerden.

Misschien speelt hier op de achtergrond ook een bepaalde misvatting mee van wat geloofsleer eigenlijk is. Mijns inziens zal de geloofsleer zichzelf als het goed is nooit verstaan als een cognitief stelsel van propositionele waarheden waarvoor geldt "slikken of stikken", maar veeleer als een hulpdienst bij het bewaren van de verrassende vondsten die de kerk in haar gang door de geschiedenis heeft opgedaan en waarachter zij niet terug wil (vgl. Van den Brink \& Van der Kooi 2012: 11). Zij houdt op deze manier inderdaad - daarin stemmen Hofmeyr, Brümmer en ik geheel samen - de wacht bij het geheim van de unio mystica, de innige gemeenschap met de Vader door de Zoon in de Geest die het hart vormt van het christelijk geloven, beleven en belijden. Maar dat de- wacht-houden-bij moet dan wel heel grondig en doordacht gebeuren. Want zoals Hofmeyr inzag: voor men het weet wordt de verborgen omgang met God de adem afgesneden doordat de propositionele vooronderstellingen onder het geloof weggeslagen worden. Juist die propositionele vooronderstellingen worden daarom in belijdenis en geloofsleer geëxpliciteerd. 
Natuurlijk - er kan scheefgroei optreden, verstarring en verintellectualisering. Maar dogmatiek is juist bedoeld om de concrete praktijken van het geloof (zoals het gebed) te verhelderen, verantwoorden en bevorderen. Ze heeft niet slechts te maken met concepten, maar is "met allerlei draden verbonden met religieuze praktijken en levende geloofsgemeenschappen" (Van den Brink \& Van der Kooi 2012: 13).

\section{TEN SLOTTE}

In het bovenstaande hebben we niet alleen een faire weergave van Brümmers nieuw te verschijnen boek willen geven, maar ook enkele vragen gesteld bij wat hij in dat boek doet en beoogt. Echter, wie weet blijken straks bij de publicatie van de nieuwe studie al die vragen volstrekt ongegrond. Dat hoop ik eigenlijk ook maar, want het zou kunnen betekenen dat de auteur - uit eigen beweging dan wel geholpen door anderen - alsnog besloten heeft om duidelijker tot uiting te laten komen dat vroomheid en rechtzinnigheid, leer en beleving, confessie en mystiek zich niet antithetisch maar veelmeer synergetisch tot elkaar verhouden.

\section{BIBLIOGRAFIE}

Brink, G. van den \& Kooi, C. van der, 2012. Christelijke dogmatiek. Een inleiding. Zoetermeer: Boekencentrum.

Brümmer, V. 2006. Brümmer on Meaning and the Christian Faith. Aldershot: Ashgate.

Brümmer, V. 2010. Hofmeyr en die mistieke teologie op Stellenbosch. Nederduits Gereformeerde Teologiese Tydskrif 51 Supplementum: 25-40.

Brümmer, V. 2012. Vroom of regsinnig? Teologie in die N.G. Kerk (typoscript d.d. 31-12-2012, 132 pp.).

Deist, Ferdinand 1986. Die wa van Ussa, ofte wel Johannes Du Plessis en die belydenisskrifte. Theologia Evangelica XIX: 59-61.

Graafland, C. 1981. Hoe en waarom kwam de Gereformeerde Bond rond de eeuwwisseling op? In: J. van der Graaf (ed.), Beproefde trouw. Vijfenzeventig jaar Gereformeerde Bond in de Nederlandse Hervormde Kerk Kampen: Kok, 13-95.

Hofmeyr, N.J. 1868. Vier leerredenen tegen de hedendaagsche dwaling of de zoogenaamde moderne theologie. Kaapstad, Hofmeijr.

Janse, C. S.L. 1985. Bewaar het pand: De spanning tussen assimilatie en persistentie bij de emancipatie van de bevindelijk gereformeerden. Houten: Den Hertog.

Kuyper, A. 1901. Drie kleine vossen. Kampen: Kok.

Muis, J. 2012. De liefde van God. Nederduits Gereformeerde Teologiese Tydskrif 53, Supplementum 3.

Murray, Andrew 1905. Het Godzalig leven. Gedachten van Graaf van Zinzendorf. Kaapstad: Christelijke Lectuur Depot.

Quispel, G. e.a., z.j. [1976]. Mystiek en bevinding. Kampen: Kok.

Sarot, Marcel 2012. Beyond Kenoticism. Why the Suffering God had to Become Man. Nederduits Gereformeerde Teologiese Tydskrif 53, Supplementum 3.

Schutte, G.J. 2010. “Den geest die eene Hoogeschool bezielt.” De Kweekschool en de Vrije Universiteit. Nederduits Gereformeerde Teologiese Tydskrif 51 Supplementum: 146-169.

\section{TREFWOORDEN}

V. Brümmer

Mystiek

Confessie/confessionalisme

N.G. Kerk

Geloofsbeleving

\section{KEY WORDS}

V. Brümmer

Mysticism

Confession/confessionalism

Dutch Reformed Church of S.A.

Experience of faith 